\title{
Determinants of Savings Among Members of Cooperative Societies in Anambra State, Nigeria
}

\author{
Anigbogu, Theresa Ukamaka (PhD) ${ }^{\mathbf{1}}$, Uzondu, Chikodiri Scholastica (PhD) ${ }^{\mathbf{2}}$, Okeke, Uju $\mathbf{M}^{\mathbf{1}}$ \\ ${ }^{1}$ Department Of Cooperative Economics And Mgt, Nnamdi Azikiwe University (NAU), Awka, Nigeria \\ ${ }^{2}$ Department Of Cooperative Economics And Mgt, Anambra State Polytechnic Mgbakwu,
}

Anambra State, Nigeria

\begin{abstract}
This study examines the determinants of savings among members of cooperative societies in Anambra state. Specifically, it provides empirical evidence on the socio-economic characteristics of members of the co-operatives and ascertains which of the socioeconomic characteristics significantly determine savings mobilization among members of the cooperative groups. It also ascertained the range of savings of the members of the cooperative groups and identified the cooperative members' reasons for saving. Data for the study were obtained from 100 cooperative members' with the aid of well structured questionnaires through a simple random sampling technique. Data were analyzed using descriptive statistics and multiple regression analysis. Results obtained showed that on the average the members
\end{abstract} saved N12, 241.57 every month. The average monthly savings is encouraging considering the fact that their monthly income is low. The major reasons for saving as indicated by the respondents include Security, Statutory as Cooperative Member, Investment and to obtain Loans. This is obtained from their mean statistics of $4.00,3.87,3.53$ and 3.00 respectively. The R2 value of 0.916 obtains indicates that about $91.6 \%$ of observed variation in savings by farmers could be attributed to the combined influence of the various independent variables included in the regression equation. The F-statistic with $95.342 \%$ was significant at 0.000 levels of significance. There is a significant variation in the range of savings of the members of the cooperative groups. Socio-economic characteristics of members significantly determine the savings of members of cooperative societies in the state. Based on the analysis and findings of this study, the researcher therefore recommends that: To increase the farmers' savings potentials, saving should be

made statutory as cooperative member. The members should also be encouraged to invest more no matter how small. It is good to save but members should have predefined reasons before saving to enable them make judicious use of whatever amount saved. There is the need to improve the livelihood strategies of the farmers to bridge the noticeable gap that exist in the farmers' savings range.

KEY WORDS: Savings, Cooperative Societies, Regressions, Multiple Regression Analysis, Loans

\section{INTRODUCTION}

Extant literature states that savings play an important role in the social and economic transformation of any economy in many instances: it forms a substantial part of capital accumulation in any given society; it has a significant influence on the circular flow of income; Not only to increase domestic savings, to achieve sustained economic growth and development but also to strengthen domestic financial intermediaries. Savings also has a direct bearing on the level of economic activity of the nation. Furthermore, savings, particularly household savings is of utmost importance in the formation of physical assets in every economy (Issahaku,2011; Sebhatu,2012; Akpan, Udoh \& Aya, 2011; Bime \& Mbanasor, 2011; Adeyemo \& Bamire, 2005). The households undertake a substantial portion of the physical investment directly and they also make public and private corporate investment possible by the transfer of saving. The implication is that the household saving behaviour determines to a large extent whether or not investment targets have been achieved. Hence, the volume of saving of the household sector and the 
form in which it is held is of crucial importance, as consumption reflects the efficiency of investment of saving (Issahaku, 2011).

At the microeconomic level, individual households save for different purposes: The rural and poor people in particular make sacrifices to ensure that they keep some reserves, especially for precautionary reasons and to protect themselves against risks such as sickness, drought and disease outbreak (Zeller et al., 1997; Bime \& Mbanasor, 2011). Sebhatu (2012), notes that household save for reasons such as liquidity constraint or life cycle savings. In developing countries savings are important determinants of household welfare. On one hand, without savings, households have few other mechanisms to smooth out unexpected variations in their income, and so, shocks may create some problems of human capital accumulation at early ages. It is averred in the literature that the sustenance of household savings increases the possibility of future investment both at the micro and macro- levels in the economy. According to Akpan, et al (2011) economic theory postulates that households' saving is the difference between households' income and consumption. Household income is aggregate income a household earns from all sources in a particular period. Consumption on the other hand, is the total amount of goods and services that is consumed by households during a particular period. Thus, higher savings lead to capital accumulation and hence economic growth.

Saving mobilization as postulated by economic theories is determined by a number of factors. Some major hypotheses in studying private savings include the Permanent Income Hypothesis of Friedman and Ando and Modigliani's Life Cycle Hypothesis. Friedman differentiates permanent and transitory components of income as determinants of savings (Nwankwo, Ewuim \&Asoya, 2013). Permanent income is defined in terms of the long time income expectation over a planning period and transitory income is the difference between actual and permanent income. There are many empirical studies on the permanent income hypothesis in the literature as shall be examined later. Ando and Modigliani in their hypothesis, individuals spread their lifetime consumption over their lives by accumulating savings during earning years and maintaining consumption levels during retirement (Nwankwo, Ewuim \& Asoya, 2013). The empirical studies are concerned with the effect of demographic factors, such as age groups
.Adeyemo and Bamire (2005) states that the amount that individual farmers could save also depends on a number of factors such as income and family size. According to Ijere (1998), credit mobilization in Nigeria, as in many developing countries is predicated on many interrelated factors, Chief of which are the economic situation of the country, the organizational structure of public and private credit institutions and the availability of investment opportunities. Saving depend, to a great extent on the volume of peoples income. The import here is that the identification of the factors that influence savings accumulation is imperative for mobilizing saving for sustainable economic and social transformation.

Cooperative societies have been closely identified with provision of financial services in the rural sector. Since its inception, cooperative in Nigeria has been viewed as a veritable tool for national development particularly in the area of socio-economic development of rural areas. Cooperative societies are organized or formed to accomplish one or more functions, including production, purchasing, supplying, marketing and provision of financial services to the members among others. It is therefore not surprising that so much emphasis is being placed on the efficacy of cooperatives as a welfare intervention tool (Nwankwo, Ewuim \& Asoya, 2013).

\section{Statement of the Problem}

Despite the role of saving to social and economic transformation in an economy, arguably, individual households in Nigeria sill have very low propensity to save which has made them remain in poverty. Nigeria is still ranked as one of the countries with a large number of poor people in the world. A greater percentage of the population earn income below one US dollar per day (Transpiracy International, 2012). Affirming this, Sanusi (2010), using the poverty rate as a proxy for growth, posits that 70 percent (105 million) of Nigerians live below the poverty line, up from 54 percent in 2010. This is a glaring paradox and sometimes subtly comprehensible that a country blessed by nature is ranked among the league of top, poverty stricken nations in the world. Following the pioneering work of Keynes in 1934 which defines savings as a linear function of income and the first major breakthrough in savings literature is the permanent income hypothesis of Friedman which identifies income as a major determinant of savings. Arguably, when income level of an individual is low his marginal propensity to save automatically 
becomes low. That is, where he even saves at all. Extant literature (Osaka, 2006; Uneze, 2013; Brata,1999; Issahaku,2011; Sebhatu,2012; Akpan, Udoh \& Aya, 2011; Bime \& Mbanasor, 2011; Adeyemo \& Bamire, 2005) is replete with factor that influence individual household saving with some similarities and variations in their findings. For example, Issahaku,2011 in his study found that age composition and assets do not have a significant effect on saving. The factors that drive household investment are occupation, expenditure, assets and saving. While the study of Uneze, 2013 revealed age of household head and value of Assets part of the significant variables affecting deposit mobilization in cooperatives by farmers in the group lending scheme. In Nigeria, with the mushrooming of various platform for mobilizing savings - formal and informal Cooperative groups have been identified to serve as useful instruments and as avenues for saving and extension of credit facilities as these informal financial institutions are mostly preferred by farmers and non farmers in both the rural and urban areas due to easy accessibility, smallness of scale, and informal nature of transactions. However, savings mobilization rates have generally remained very low in the subsector (see Tesfamariam, 2012; Uneze, 2013). The study of Uneze, 2013 revealed that significant variables affecting deposit mobilization in cooperatives by farmers in the group lending scheme were value of Assets, off farm income, age of household head, level of farm diversification and total value of farmer's loan. Thus warranting an empirical probing among members cooperative groups to reaffirm some of the social and economic factors included in his model and also ascertain other social and economic factors influence savings. Given that, it is still in doubt as a result of paucity of empirical literature on what factors actually determines household savings mobilization among members of cooperative groups Anambra state.

\section{Objectives of the Study}

The main objective of the study is to examine the determinants of savings among members of cooperatives in Anambra State. Specifically, the study intends to:

1. Ascertain the amount of savings by members with the aim determining their savings potentials.

2. Examine the influence of socio-economic characteristics of members of cooperatives on the amount the amount of savings mobilized.
3. Ascertain the reasons for saving by cooperative members.

\section{Statements of Hypotheses}

The following hypotheses which are in null forms are intended to guide the course of the study:

Ho1 : There is no significant variation in the savings of the members of the cooperatives.

Ho2 : The socio-economic characteristics of members of cooperatives significantly determine the amount the amount of savings mobilized.

\section{Empirical Review}

The role of savings in economic development is very important and it can be described as a driving force necessary for economic growth. Economic theory postulates that capital accumulation is the prerequisite for both economic growth and development. Savings is influenced by individual habits. The saving habits of a person is measured by his or her marginal propensity to save which is in turn is determined by the disposable income and the marginal propensity to consume, which is in turn determined by a number of factors (Bime and Mbanasor, 2011). To further understand the determinant factors of savings, a number of empirical literatures are reviewed to unearth the various perspectives.

Bime and Mbanasor (2011) examined the socioeconomic determinants of informal savings amongst vegetable farmers in the North West Region, Cameroon. Data for the study were obtained from 180 farmers with the aid of well structured questionnaires through a multistage sampling technique. Data were analyzed using descriptive statistics and multiple regression analysis. Results obtained showed that vegetable farmers were on the average 36 years with average household size of 7 . Average farm size of 0.5 ha cultivated indicates small nature of holdings. Results from the multiple regression analysis showed that interest paid, farm size, income, education and distance were positively significant while gender, age and household size were also significant and negative. Issahaku (2011) adopted a microeconomic approach of estimating the determinants of financial saving and investment in one of the most deprived district capitals in Ghana, the Nadowli in the Nadowli District of the Upper West Region. Two separate multiple linear regression models were fitted for saving and investment. The Paper found that there is the propensity to save and invest in Nadowli in spite of low income. Whereas the levels of income, 
educational status, occupation, have positive influence on saving, the number of dependents exerts a negative influence on saving. The paper found that age composition and assets do not have a significant effect on saving. The factors that drive household investment are occupation, expenditure, assets and saving. Adeyemo and Bamire (2005) examined the pattern of saving and investment among four hundred cooperative farmers in south-western Nigeria. Data were collected using structured questionnaires. Data were analysed using descriptive statistics and multiple regression technique. Results show that cooperative farmers in south-western Nigeria are mostly males, literate and of average age of 47 years. About $40 \%$ of total capital borrowed was expended on farm work and mean annual total investment was N75, 043.00, with cooperative farmers earning more than 3 times the investment made. Average annual savings was $\mathrm{N} 31,572.00$ and this increased in proportion to annual incomes in the area. However, the unavailability and inadequacy of credit was a major problem of the farmers. Different factors influenced cooperative farmers' saving and investment patterns. Income, loan repayment and amount of money borrowed were significant variables that influenced saving patterns while the fund borrowed significantly influenced investment patterns. Sebhatu (2012) investigated the determinants of saving behaviour of cooperative members in Tigrai region of Ethiopia. The data for the study was obtained from randomly selected 120 rural household savers from eight financial cooperatives. The empirical analysis, using multiple regression model shows that gender, household income, amount of loan borrowed and year of cooperative membership significantly raise household savings.

Akpan et al (2011) carried out a study to determine factors that affect household saving of rural agrobased firm workers in the south-south region of Nigeria. Two-stage least squares method of simultaneous equation model was used in the analysis. Cross-sectional data were collected from 250 randomly selected workers of five agro-based firms in the study areas. The results of the analysis revealed that income, tax, job experience, education, family size and membership of a social group influence saving attitude of workers. Nwankwo, Ewuim and Asoya (2013) assessed the effect of cooperative on the savings behaviour of members. The study was carried out in Oyi LGA with data from 195 randomly selected members of credit cooperatives. Analysis of data was with descriptive statistical tools such as mean, tables, and frequency counts. Also a multiple regression model was utilized to assess determinants of savings behaviour. Results from the study show that cooperative membership impacted positively on the savings behavior of members. Findings show that older members had more savings than newer members. Although the marginal propensity to save (MPS) was a 9.3\%, it was significant since it showed that rural dwellers were capable of saving in cash. Moreover most of these savings were made through the savings mechanism of cooperatives. Length of membership in cooperative was also found to be an important determinant of savings thus confirming that the older one is in the cooperative, the more he is likely to save. Brata (1999) examined Household Saving Behaviour: The case of rural industry in Bantul. Using an econometric model of life-cycle theory, this study also found that household saving was determined by household's income, both of education level and sex of the industry holders, and the varieties of industries. Uneze (2013) examined how the socio-economic factors of farmer-members of cooperative in agricultural group lending scheme influence their abilities to make financial savings with their cooperatives. The study was conducted in Anambra State, Nigeria. Frequency distribution, percentages and means were descriptive statistics used in analyzing data. The lead function from regression analysis showed that 43.08 percent of the total variation in deposit mobilization was explained by the 10 socio-economic variables included in the model. The significant variables affecting deposit mobilization in cooperatives by farmers in the group lending scheme were value of Assets, off farm income, age of household head, level of farm diversification and total value of farmer's loan. More so, the study found that the financial savings mobilized by farmer-members within their cooperatives were meagre averaging $\$ 1595$ and made usually for purpose of securing loans.

Pailwar, Kaur, Saxena and Nijhara (2010) examined the impact of membership of financial institutions on rural saving: a micro-level study in India. This micro study, aims at ascertaining the significance of financial institutions in mobilizing financial saving of rural/ semi-urban households. It is based on the primary data collected from full scale sample survey conducted in five villages and two suburban areas of National Capital Region, India. A hierarchal regression carried out on this data identified that the membership of financial institutions, specifically that 
of banks, insurance and informal financial institutions explains significant proportion of the variation in the rural household financial saving.

Empirical studies by researchers to determine factors affecting saving behaviour and volume of savings of rural households have been reviewed. The empirical literatures reviewed placed more emphasis on determinant factors affecting saving behaviour. In other words, majority of the study focused on factors that influence the decision of individual households to save or not to save and their investment pattern. A good number of the studies were carried out side the shores of this country. However, similar studies like the work of Nwankwo et al (2013)- was limited in scope to a local government- and Uneze (2013)- was inadequate for generalization, thus suggesting the lack of adequate empirical studies on determinants of savings mobilization. This study fills a gap in the literature by investigating determinants of savings mobilization among Cooperative groups in Anambra State so as to validate and affirm factor affecting savings mobilization among Cooperative groups in Anambra State.

\section{METHODOLOGY \\ Area of Study}

This study will be carried out in three selected local government areas across the three senatorial zones in Anambra state. The local governments include: Anambra West in Anambra North Senatorial Zone; Idemili South in Anambra Central Senatorial Zone; and Orumba South in Anambra South Senatorial Zone.

Anambra West is a Local Government Area in Anambra State, South-East Nigeria. Towns that make up the local government are Ezi Anam, Ifite Anam, Nzam, Olumbanasa, Oroma-etiti, Umueze-Anam, Umuenwelum Anam. Anambra west is located in the western part of Anambra state. Its local government headquarters is Nzam (Wilkipedia, 2012).

Idemili South Local Government - Idemili south is a local government area in Anambra state, south-east Nigeria. Towns that make up the local government are Akwaukwu, Alor, Akwa-ekiti, Nnobi, Nnokwa, Oba, and Ojoto. Idemili south local government is one of the 21 local government area that make up Anambra state. It was created out of old ldemili local government in 1996 with the headquarters at Ojoto. It derives its name from Idemili River which has its source at Nri through Nnobi, Obosi and emptied in the Niger River. Idemili south is geographically bounded in the north by Idemili north local government area, in the west is Ogbaru local government area, in the south by Ekwusigo local government area while by east is Nnewi north local government and Anaocha local government. The inhabitants of Idemili south local government are predominantly traders and farmers. They speak common languages known as Igbo and English languages (Anambra, 2012).

Orumba South is a Local Government Area in Anambra State, south-East Nigeria. Umunze is the headquarters of Orumba South. Other towns that make up the local government are Akpu, Umuomaku, Eziagu, Ezira, Ubaha,Ihite, Nkerehi, Nawfija, Ogboji, Ogbunka, Owerre-Ezukala, Agbudu, Onneh, Isulo, Alaohia,Obuluhu,Uhuala,Ubaha akwaosa,Akata, Enugwu-Umuonyia (Wilkipedia, 2012).

\section{Population of the Study}

The population of this study is made up of all the members of the registered Cooperative societies in the three (3) selected Local Government Areas. Anambra West L.G.A has 46 registered cooperative societies. Idemili South L.G.A has 142 registered cooperative societies; Orumba South L.G.A has 219 registered cooperative societies. All the societies have membership strength of 6165 (Cooperative Department, Ministry of Commerce, Industry and Tourisms, Awka).

\section{Sample Size and Sampling Technique}

Two cooperative societies were randomly selected from each of the three (3) selected local governments in the three (3) senatorial zones of the state, making a total of six (6) cooperative societies, with membership strength of one hundred and sixteen (116). Taro Yamain formula was used to determine a sample size of 89.

\section{Method of Data Analysis}

Data collected were analyzed through the use of descriptive and inferential statistical tools such as means and percentages as well as multiple regression technique of analysis. Objective 1 and 2 were analyzed with the use of descriptive statistical tools. While objectives 3 was analyzed with the use of mean, standard deviation. Hypothesis one was tested using regression model. Hypotheses 2 and 3 were tested using t-test statistics. The estimated model for determinants of savings mobilization among 
International Journal of Trend in Scientific Research and Development (IJTSRD) ISSN: 2456-6470

cooperative groups in Idemili south local government area of Anambra state is implicitly shown as follows:

$\mathrm{Y}=\mathrm{f}\left(\mathrm{X}_{1}, \mathrm{X}_{2}, \mathrm{X}_{3}, \mathrm{X}_{4}, \mathrm{X}_{5}, \mathrm{X}_{6}, \mathrm{X}_{7}, \mathrm{X}_{8}, \mathrm{X}_{9} \mathrm{U}\right)$

Where

$\mathrm{y} \quad=$ amount saved (Naira)

$\mathrm{X}_{1}=$ Cooperative experience (In Years)

$\mathrm{X}_{2}=$ Age (Years);

$\mathrm{X}_{3}=$ Household size (In Number);
$\mathrm{X}_{4}=$ Farm size (Hectares);

$\mathrm{X}_{5}=$ Distance to savings institution (KM);

$\mathrm{X}_{6}=$ Household Income (Naira)

$\mathrm{X}_{7}=$ Educational level (Yrs spent in school);

$\mathrm{X}_{8}=$ Interest on saving (in \%)

$\mathrm{X}_{9}=$ Household expenditure (In naira)

$\mathrm{U}=$ error term

\section{DATA PRESENTATION AND ANALYSIS}

Table 1: Mean Monthly Savings of respondents.

\begin{tabular}{|c|c|c|c|c|c|c|}
\hline \multirow{2}{*}{ Variable } & N & Minimum & Maximum & \multicolumn{2}{|c|}{ Mean } & Std. Deviation \\
\cline { 5 - 7 } & Statistic & Statistic & Statistic & Statistic & Std. Error & Statistic \\
\hline Savings of members & 89 & 5500 & 45500 & 12241.57 & 1116.037 & 10528.671 \\
\hline Valid N (list wise) & 89 & & & & & \\
\hline
\end{tabular}

Source: Field Survey, 2017

Table 1 shows the monthly range of savings of the members of the cooperatives. On the average the members save $\$ 12,241.57$ every month. The least monthly savings by a member was N5, 500 while the highest savings amount was $\mathrm{N} 45,500$. This wide disparity in saving was also reflected in the standard deviation. Nevertheless, the average monthly savings is encouraging considering the fact that their monthly income is low: majority of the respondents earned between $\mathrm{N} 20,100$ and N30,000 monthly.

Table 2: Distribution according to respondents reasons for saving

\begin{tabular}{|c|c|c|c|c|c|}
\hline & $\mathbf{N}$ & MIN & MAX & Mean Statistic & Std. Deviation Statistic \\
\hline Obtain Loans & 89 & 1 & 4 & 3.00 & .769 \\
\hline Security & 89 & 4 & 4 & 4.00 & .000 \\
\hline Emergencies/income smothing & 89 & 3 & 4 & 2017.91 & .288 \\
\hline Housing & 89 & 1 & 4 & 2.78 & .997 \\
\hline Purchse Appliances & 89 & 2 & 4 & 2.66 & .811 \\
\hline Purchase Farm Inputs & 89 & 2 & 4 & 2.78 & .938 \\
\hline Education & 89 & 1 & 4 & 2.35 & .067 \\
\hline Investment & 89 & 2 & 4 & 3.53 & .343 \\
\hline Statutory as Coop. Members & 89 & 3 & 4 & 3.87 & \\
\hline Valid N (listwise) & 89 & & & & \\
\hline
\end{tabular}

Source: Field Survey, 2017

From table 2 the major reasons for saving as indicated by the respondents include security, statutory as cooperative member, investment and to obtain Loans. This is obtained from their mean statistics of 4.00, 3.87, 3.53 and 3.00 respectively.

\section{Tests of Hypotheses}

\section{Hypothesis one:}

Ho1: There is no significant variation in the savings of the members of the cooperative societies.

Ha1: There is a significant variation in the savings of the members of the cooperative societies.

Table3: T-test result on differences in variation of savings of members of the cooperative

\begin{tabular}{|c|c|c|c|c|c|c|}
\hline \multirow{3}{*}{ Variable } & \multicolumn{6}{|c|}{ Test Value $=0$} \\
\hline & \multirow[t]{2}{*}{$\mathbf{t}$} & \multirow[t]{2}{*}{ Df } & \multirow[t]{2}{*}{ Sig. (2-tailed) } & \multirow[t]{2}{*}{ Mean Difference } & \multicolumn{2}{|c|}{$\begin{array}{c}95 \% \text { Confidence Interval } \\
\text { of the Difference }\end{array}$} \\
\hline & & & & & Lower & Upper \\
\hline Savings of coop members & 10.969 & 88 & 0.000 & 12241.573 & 10023.68 & 14459.46 \\
\hline
\end{tabular}

Source: Field Survey, 2017 
Hypothesis one states that there is no significant variation in the savings of the members of the cooperative groups. To test the hypothesis the t-test statistics was employed. Table 3 is a summary of the t-test values on the mean differences in the opinion of the farmers. The result of the test shows that the t-calculated value was significant at 0.000 significant levels. This implies that there is a significant variation in the range of savings of the members of the cooperative societies, hence, the need to improve the livelihood strategies of the farmers to bridge the noticeable gap that exist in the farmers savings range.

\section{Hypothesis two:}

Ho2 : The socio-economic characteristics of members of cooperative groups do not determine the savings of cooperative members.

.Ha2 : The socio-economic characteristics of members of cooperatives significantly determine significantly savings of cooperative members.

Table 4: Socio-economic characteristics influencing savings among members of cooperatives (Regression Result)

\begin{tabular}{|l|l|l|l|c|}
\hline \multicolumn{1}{|c|}{ Model } & \multicolumn{1}{c|}{ B } & Std. error & \multicolumn{1}{c|}{ T } & Sig. \\
\hline CONSTANT & 0.987 & 0.089 & 11.121 & 0.066 \\
\hline Duration of Cooperative Membership & 71.894 & 2.939 & 24.459 & 0.021 \\
\hline Age & -19.546 & 19.546 & -1.755 & 0.283 \\
\hline Household Size & -12.433 & 2.893 & -4.297 & 0.000 \\
\hline Farm Size & 41.831 & 6.326 & 6.613 & 0.012 \\
\hline Distance to the savings Institution & -24.536 & 2.683 & 9.145 & 0.000 \\
\hline Household Income & 10.137 & 0.842 & 12.039 & 0.001 \\
\hline Educational Qualification & 0.104 & 0.024 & 4.242 & 0.000 \\
\hline Interest paid on savings Trenditure & 1.748 & 0.668 & 2.617 & 0.041 \\
\hline Household Expenditur| & -0.242 & 0.063 & -3.832 & 0.000 \\
\hline R Pesea & 0.957 & & & \\
\hline $\mathbf{R}^{\mathbf{2}}$ & 0.916 & & 0 & \\
\hline Adj. $\mathbf{R}^{\mathbf{2}}$ & 0.906 & & & \\
\hline F-statistic & 95.342 & & & 0.000 \\
\hline
\end{tabular}

Dependent variable: Amount saved

Table 4 shows socio-economic characteristics influencing savings among members of cooperative societies in Anambra State. The model was presented in the linear form. The linear functional form was chosen based on the high value of the $R^{2}$, more significant coefficients and expected signs. The $\mathrm{R}^{2}$ value of 0.916 obtains indicates that about $91.6 \%$ of observed variation in savings by farmers could be attributed to the combined influence of the various independent variables included in the regression equation. The F-statistic with 95.342 was significant at 0.000 levels of significance. With the exception of age which was not significant, cooperative experience, Household size, Farm size, Distance to savings institution, Household Income, Educational level, Interest on saving, Household expenditure are significant determinants of savings among cooperative societies in the Anambra state. In view of the fact that the $\mathrm{F}$ ratio with a value of $95 \%$ was significant at 0.00 levels, we reject null hypothesis and accept the alternate and then conclude that socioeconomic characteristics of members significantly determine the savings of members of cooperative societies in the state.

\section{Conclusion and Recommendations}

From the analysis of the study we deduce that:

1. On the average the members saved $\$ 12,241.57$ every month. The average monthly savings is encouraging considering the fact that their monthly income is low. However, their saving potential could be as a result of their membership of cooperative.

2. The major reasons for saving as indicated by the respondents include Security, Statutory as Cooperative Member, Investment and to obtain Loans. This is obtained from their mean statistics of $4.00,3.87,3.53$ and 3.00 respectively. 
3. The $\mathrm{R}^{2}$ value of 0.916 obtains indicates that about $91.6 \%$ of observed variation in savings by farmers could be attributed to the combined influence of the various independent variables included in the regression equation. The F-statistic with $95.342 \%$ was significant at 0.000 levels of significance.

4. There is a significant variation in the range of savings of the members of the cooperative groups, hence, the need to improve the livelihood strategies of the farmers to bridge the noticeable gap that exist in the farmers' savings range.'

5. Socio-economic characteristics of members significantly determine the savings of members of cooperative societies in the state.

Based on the analysis and findings of this study, the researcher therefore recommends that:

1. To increase the farmers' savings potentials, saving should be made statutory as cooperative member. The members should also be encouraged to invest more no matter how small.

2. It is good to save but members should have predefined reasons before saving to enable them make judicious use of whatever amount saved.

3. There is the need to improve the livelihood strategies of the farmers to bridge the noticeable gap that exist in the farmers' savings range.

\section{References}

1. Adeyemo, R. \& Bamire, A.S (2005) Saving and Investment Patterns of Cooperative Farmers in Southwestern Nigeria. Journal of Social Sciences, 11(3), 183-192.

2. Akpan, S.B, Udoh, E.J \& Aya, E.E (2001). Analysis of Savings Determinants Among Agrobased Firm Workers in Nigeria: A Simultaneous Equation Approach. Research on Humanities and Social Sciences. 1(3),

3. Bime, M. J. \& Mbanasor, J. (2005). Determinants of informal savings amongst vegetable farmers in North West Region, Cameroon. Journal of
Development and Agricultural Economics, 3(12), 588-592.

4. Brata, A. G. (1999). Household Saving Behaviour: The case of Rural Industry in Bantul .Analisis CSIS 28 (1), 75-86.

5. Issahaku, h. (2011). Determinants of Saving and Investment in Deprived District Capitals in Ghana -A Case Study of Nadowli in the Upper West Region of Ghana. Wilolud Journals, http://www.wiloludjournal.com

6. Nwankwo, F., Ewuim, Ngozi \& Asoya, N.P. (2013). Effect of Cooperatives on the Savings Behaviour of Members in Oyi Local Government Area, Anambra State, Nigeria. International Multidisciplinary Journal, Ethiopia, 7(1), 209227.

7. Osaka, J.I. (2006). An Analysis of Savings and Investment Behaviour of Farmers in Giwa and Sabon-Gari Local Government Areas of Kaduna state.A Thesis Submitted to the Postgraduate School of Ahmadu Bello University, Zaria, in Partial Fulfilment of the Requirements for the Award of the Degree of Master of Science in Agricultural Economics. Ahmadu Bello University, Zaria Nigeria

8. Pailwar, V. K, Kaur J. Saxena, K \& Nijhara, M (2010) Impact Of Membership Of Financial Institutions On Rural Saving: A Micro-Level Study. International Business \& Economics Research, 9(10), 139

9. Sebhatu, K.F (2012) Determinants of saving Behaviour of cooperative members survey evidence from Tigrai region, Ethiopia. Journal of Research in Economics and International Finance (JREIF), 1(5), 150-158.

10. Uneze, C. U. (2013). Socio-Economic Determinants of Savings in Cooperatives by Farmers of Selected Agricultural Group Lending Schemes in Anambra State, Nigeria. Greener Journal of Agricultural Sciences. 3 (5), 384-390. 